\title{
PENYELESAIAN KREDIT MACET DI KOPERASI SUMBER KASIH DESA TANGEB KECAMATAN MENGWI KABUPATEN BADUNG
}

\author{
I Kadek Nova Astrawan, Anak Agung Sagung Laksmi Dewi, Luh Putu Suryani \\ Fakultas Hukum Universitas Warmadewa, Denpasar-Bali, Indonesia \\ laksmiidewi29@gmail.com, putusuryani099@gmail.com
}

\begin{abstract}
Abstrak
Indonesia merupakan negara berkembang dengan perkembangan ekonorninya yang sangat beragam. Diikat oleh peraturan pemerintah masyarakat tidak bisa sembarangan dalam bertindak dan harus mengikuti norma yang berlaku. Pemerintah dalam upaya menyetarakan kesejahteraan masyarakatnya membuat wadah perkumpulan masyarakat untuk mengelola dana yang dimiliki atau pinjaman dana untuk membuka suatu usaha. Tujuan penelitian ini guna mengungkap pengaturan hukum kredit macet pada KSU Sumber Kasih desa Tangeb serta penyelesaian terhadap kredit macet di KSU Sumber Kasih desa Tangeb. Penelitian ini mengaplikasikan metode penelitian normatif. Sumber data yang digunakan berupa bahan hukum primer dan sekunder. Penelitian ini dilakukan dengan mencari data langsung kelapa ngan dan melalui buku ilmu hukum dan menghubungkan dengan permasalahan yang diangkat kemudian mengkaitkan dengan perundang-undangan yang berlaku saat ini yang kemudian dianalisis secara sistematis. Hasil penelitian mengungkapkan bahwa Bank Perkreditan Rakyat merupakan solusi pemerintah memberi kemudahan pada masyarakat tapi dengan syarat dan ketentuan dalam proses peminjaman. Setiap masyarakat yang ingin meminjam uang untuk keperluan tertentu dapat dilakukan di BPR, bagi yang ingin meminjam modal harus memiliki jaminan yang nantinya akan dikalkulasikan sesuai dengan pinajaman yang diinginkan namun tidak jarang staf bank tidak memikirkan jumlah jaminan yang digunakan dengan dana yang dipinjam membuat sering terjadi wanprestasi.
\end{abstract}

Kata Kunci: Koperasi Sumber Kasih, Kredit Macet, Penyelesaian

\begin{abstract}
Indonesia is a developing country with various kinds of economic development. Bound by government regulations, the community cannot act arbitrarily and must follow applicable norms. The government in an effort to equalize the welfare of its people creates a forum for community associations to manage their funds or borrow funds to open a business. The purpose of this study is to reveal the legal arrangements for bad loans at KSU Sumber Kasih, Tangeb village and the settlement of bad loans at KSU Sumber Kasih, Tangeb village. This research applies normative research methods. Sources of data used in the form of primary and secondary legal materials. This research was conducted by looking for direct data from the field and through legal science books and connecting with the issues raised and then linking them to the current legislation which was then analyzed systematically. The results of the study reveal that Rural Banks are the government's solution to provide convenience to the community but with terms and conditions in the lending process. Every community who wants to borrow money for certain purposes can be done at BPR, those who want to borrow capital must have collateral which will later be calculated according to the desired loan, but it is not uncommon for bank staff not to think about the amount of collateral used with borrowed funds, this often happens. default.
\end{abstract}

Keywords: Sumber Kasih Cooperative, Bad Credit, Settlement

\section{PENDAhUluan}

Dalam perekonomian Indonesia, Negara sebagai wadah dari rakyat untuk meningkatkan kesejahteraan rakyat. Di era sekarang uang menjadi yang utama bisa dikatakan dengan uang seseorang dapat memiliki apapun. Percaya tidak percaya Indonesia da pat bertahan karena pajak yang dihasilkan dari setiap penghasilan masyarakat serta meningkatkan perekonomian dari masyarakat dan nasional. Semakin padatnya penduduk maka semakin banyak orang yang memerlukan uang demi bertahan hidup. Koperasi Sumber Kasih Tangeb merupakan solusi bagi masyarakat guna menekan angka kemiskinan namun demi bisa mendapatkan modal usaha harus mengisi formulir serta mengikuti syarat dan ketentuan. Lembaga keuangan merupakan alternatif terbaik saat ini bagi masyarakat yang ingin mengernbangkan usaha demi meningkatkan sumber pendapatnya namun demi mendapatkan 
pinjaman memerlukan beberapa syarat seperti jaminan yang setara dengan modal yang ingin dipinjam serta ketentuan bunga yang berlaku di setiap koperasi berbeda-beda tergantung besar dana pinjaman. Sasaran Koperasi Sumber Kasih Tangeb adalah masyarakat dengan ekonomi menengah kebawah, biasanya jika ada masyarakat ekonomi menengah keatas akan dipertimbangkan terlebih dahulu baru diputuskan apakah mendapat pinjaman dana atau tidak namun bagi masyarakat ekonomi menengah kebawah akan dipermudah dalam proses peminjaman dana. Koperasi Sumber Kasih Tangeb dalam memberikan pinjaman harus dilakukan dengan perjanjian kredit yang disepakati oleh peminjam. Dengan adanya perjanjian kredit ini di satu pihak, peminjam memperoleh kredit tersebut dengan harapan agar usaha yang dilakukan dapat berkembang dan dapat memenuhi kebutuhannya yang lain. Sedangkan pada pihak Koperasi memperoleh keuntungan dari pemungutan bunga kredit. Disamping itu untuk menjamin pelunasan utangnya dalam perjanjian kredit tersebut, pihak peminjam diharuskan memberi kan jaminan kepada pihak Koperasi sebagai pelunasan utang apabila si peminjam suatu saat tidak bisa melunasi pinjamannya kepada pihak Koperasi. Jadi sudah seharusnya apabila masingmasing pihak dalam suatu perjanjian yang telah diadakan harus melaksanakan isi perjanjian yang telah disepakati. Setiap pihak yang melakukan perjanjian harus memiliki itikad baik yaitu mematuhi setiap isi perjanjian dan tidak melakukan wanprestasi yang berakibat batalnya suatu perjanjian (Uchsan, 2001).

Para pihak melakukan perjanjian terlebih dahulu mendiskusikan isi perjanjian yang akan ditandatangani dan melaksanakan kewajiban demi mendapatkan hak. Jangan ada salah satu pihak tidak setuju namun perjanjian tetap dilaksanakan, hal tersebut membuat selisih paham yang berujung terjadi wanprestasi. Bila terjadi ingkar janji maka perjanjian tidak dapat berjalan lagi serta terjadi kemungkinan penuntutan hak oleh pihak yang merasa dirugikan, jika pinjaman atau kredit mengalami kemacetan hingga sampai pihak peminjam tidak memenuhi pelaksanaan perjanjian yaitu pelunasan kredit, maka jaminan si debitur akan ditarik oleh pihak Koperasi sebagai pelunasan utang atau kredit si peminjam. Pihak bank dapat mengajukan permohonan pelelangan jaminan tersebut ke Kantor Lelang atau benda yang menjadi jaminan tersebut. dapat dijual bersama-sama oleh pihak Koperasi dan debitur guna mewujudkan pemenuhan prestasi yang menjadi haknya jika debitur ternyata melakukan wanprestasi. Perwujudan prestasi disini tidak memerlukan perantara hakim karena debitur disini telah menyetujui cara demikian sesuai dengan isi dari perjanjian kredit yang telah disepakati. Pelaksanaan pemenuhan prestasi yang dilakukan sendiri oleh kreditur semacam ini disebut eksekusi langsung. Kendala yang sering terjadi dikala jaminan masyarakat tidak sesuai dengan pinjaman yang diberikan sering kali pihak bank lalai atau tidak memperhitungkan jaminan masyarakat dengan pinjaman yang diberikan membuat bank menjadi rugi.

Permasalahan yang timbul kemudian adalah di satu pihak, apabila setelah melakukan pelelangan atau penjualan benda jaminan milik debitur bersama-sama dengan pihak koperasi ternyata jaminan yang dibayarkan oleh debitur masih bernilai kurang atau jaminan tersebut tidak dapat mencukupi pelunasan utang kreditur kepada pihak bank. Sedangkan di sisi lain, pihak Koperasi harus menuntut pemenuhan prestasi berupa pe lunasan utang dari pihak debitur. Terkait dengan masalah tidak mencukupinya hasil eksekusi benda jaminan kredit untuk pelunasan utang debitur kepada pihak bank. Pada setiap perjanjian masing-masing pihak diwajibkan untuk memenuhi apa yang menjadi isi dari perjanjian atau dapat dikatakan bahwa masing-masing pihak wajib untuk memenuhi prestasinya, perjanjian kredit menimbulkan hak dan kewajiban bagi para pihak yang membuat perjanjian kredit sehingga dalam pelaksanaannya perjanjian kredit juga dapat menimbulkan akibat hukum bagi pihak kreditur dan debitur yang menyepakatinya.

Terdapat penelitian terdahulu yang relevan dengan penelitian ini. Salah satunya (Suarjaya, 2015) yang meneliti didaerah Klungkung, hasil penelitian menunjukkan bahwa penyebab terjadinya kredit macet pada Koperasi Pasar Srinadi Klungkung, terdapat dua faktor penyebab yang ditemukan, yaitu (1) faktor intern dan (2) faktor ekstern. (1) faktor intern terdiri dari tiga variabel yaitu: (a) kurang selektifnya pihak koperasi dalam analisis pemberian kredit, (b) itikad tidak baik dari petugas Koperasi Pasar Srinadi Klungkung, dan (c) lemahnya sistem pengawasan kredit. (2) faktor ekstern terdiri dari tiga variabel yaitu: (a) penurunan kondisi perekonomian, (b) itikad tidak baik dari debitur, dan (c) akibat bencana alam. Sedangkan (Sari et al., 2019) memberikan pernyataan bahwa salah satu upaya penyelesaian kredit macet pada Koperasi Simpan Pinjam Karya Arha Sedana dan KSP. Wirartha Utama di Kota Denpasar Selatan yaitu melelui mekanisme pemanggilan yang dilakukan oleh 
pihak koperasi selaku kreditur bertujuan untuk mengetahui penyebab debitur belum bisa melunasi hutangnya. Dalam perjanjian kredit pada Koperasi Simpan Pinjam Karya Artha Sedana dan KSP. Wirartha Utama Di Kota Denpasar Selatan sebaiknya pihak koperasi lebih maksimal dalam melakukan pengawasan terhadap kreditur agar kredit yang diberikan tidak disalahgunakan oleh debitur. Adapun menurut (Surya et al., 2021) faktor-faktor yang menyebabkan terjadinya kredit macet pada koperasi ialah faktor internal merupakan faktor penyebab kredit macet yang berasal dari pihak koperasi itu sendiri, Faktor ekternal merupakan faktor penyebab kredit macet yang berasal dari pihak nasabah. Penyelesaiain kredit macet ditempuh melalui non-litigasi dan litigasi.

Berdasarkan uraian diatas, maka dapat dirumuskan tujuan dari penelitian ini yaitu guna mengungkap pengaturan hukum kredit macet pada KSU Sumber Kasih desa Tangeb serta penyelesaian terhadap kredit macet di KSU Sumber Kasih desa Tangeb.

\section{METODE PENELITIAN}

Penelitian ini dilakukan dengan mencari data langsung kelapa ngan dan melalui buku ilmu hukum dan menghubungkan dengan permasalahan yang diangkat kemudian mengkaitkan dengan perundangundangan yang berlaku saat ini. Dari segi hukum penelitian ini termasuk penelitian empiris (Waluyo, 2002). Penulis mengkaitkan dengan peraturan yang berlaku dan tidak menyimpang dari undangundang dasar. Pendekatan penelitian dengan cara mengkaji, mencari dan memilah data dari berbagai buku hukum dan berpatokan pada undang-undang sebagai dasar penulisan penelitian. Penelit ian ini bertujuan mencari informasi yang akurat dengan mempelajari gejala masyarakat untuk mendapatkan data yang sebenar-benarnya. Dengan demikian data dapat digabungkan dengan berbagai referensi buku hukum yang terkait dan menghasilkan yang tida $\mathrm{k}$ melenceng dari hukum positif (Ahmad, 2008). Penulis meneliti kasus ini menggunakan metode normatif. Dimana dalam pengerjaannya penulis mengumpulkan informasi dengan menelaah dan menganalisa buku-buku hukum yang didasari peraturan-peraturan hukum yang berlaku di Indonesia.

\section{HASIL DAN PEMBAHASAN}

\section{Pengaturan Hukum Kredit Macet Pada KSU Sumber Kasih Desa Tangeb}

Sudah diketahui banyak orang bila ses eorang ingin meminjam modal usaha harus ada jaminan yang harga jualnya sesuai modal yang dipinjam, kegiatan ini dilakukan oleh lembaga-lembaga keuangan kepada nasabah atau anggota mereka golongan ekonomi menengah kebawah. Tidak semudah yang terlihat sebelum melakukan pinjaman harus mengisi formulir serta mengajak salah satu sanak saudara sebagai saksi telah dilakukannya perjanjian pinjam dana antara nasabah dengan pihak lembaga keuangan. Koperasi Sumber Kasih Tangeb dalam melakukan suatu perjanjian para pihak harus sepakat mengenai isi perjanjian, para pihak yang bersangkutan secara bersama-sama terlebih dahulu mendiskusikan isi perjanjian agar tidak ada pihak tidak menyukai perjanjian. Tujuan perjanjian sendiri mempermudah para pihak untuk saling mendap atkan hak tanpa melupakan kewajiban, hal itu selalu ada di perjanjian. Para pihak harus memahami dasar perjanjian seperti arti kata sepakat, kewajiban dulu lalu mendapatkan hak, sanksi bagi pihak yang terbukti melakukan wanprestasi serta harus berisi kuasa hukum, nantinya kuasa hukum yang mengarahkan para pihak menyelesaikan perkara akibat wanprestasi salah satu pihak. Isi perjanjian kredit tersebut dari pihak debitur sudah harus mengerti akan isi perjanjian kredit tersebut, karena dalam perjanjian tersebut, debitur yang tidak melunasi hutangnya sudah menyadari bahwa barang berharganya, baik barang yang bergerak maupun yang tidak bergerak, baik yang sudah ada maupun yang akan ada dikemudian hari, akan menjadi jaminan dan bank akan menyita benda atau harta ke kayaan milik debitur tersebut untuk menutupi kekurangan pelunasan utang debitur. Sesuai perjanjian kredit tersebut, maka pihak bank dapat menyita bendabenda atau harta kekayaan milik debitur melalui penetapan pengadilan. Kemudian diajukan permohonan kepada kantor Lelang untuk mengambil harta kekayaan debitur yang lain untuk melunasi hutang-hutang debitur.

Sebuah perjanjian yang memasukan kuasa hukum untuk mengamankan aset masing-masing jika suatu hari terjadi wanprestasi tugas kuasa hukum memberi pilihan penyelesaian sengketa mulai dari memakan waktu dan tenaga yang banyak sampai penyelesaian alternatif atau yang lagi booming belakangan tahun ini (Atmadja, I Dewa Gede Budiartha, 2018). Dua cara penyelesaian sengketa yaitu litigasi dan non litigasi, keduanya memiliki aturan ketentuan berbeda. Mulai dari jalur litigasi, setiap 
pihak merasa dirugikan mengajukan gugatan melalui pengadilan, mempercayakan putusan dan aturan main oleh hakim ketua. Biasanya setiap orang yang melakukan litigasi sudah tidak menemukan titik terang dari negosiasi dari penyelesaian secara non litigasi. Aturan waktu serta pemanggilan beberapa orang yang menjadi saksi membuat proses litigasi berjalan lambat, butuh waktu beberapa bulan menye lesaikan tuntutan yang diajukan. Memilih jalur non litigasi atau jalur singkat penyelesaian masalah sangat tepat karena proses tidak membutuhkan waktu lama seperti jalur litigasi (Hermansyah, 2003). Cara penyelesaiannya cukup mudah yaitu kedua belah pi hak melakukan negosiasi atau mencari jalan tengah agar perjanjian kembali berlanjut dan selesai sesuai isi perjanjian yang sudah disepakati bersama. Secara meluas penyelesaian sengketa non litigasi dapat dilakukan efisien waktu dan dana tidak begitu besar yaitu :

1. Penjadwalan kembali (rescheduling), yaitu proses yang dilakukan antara kedua belah pihak dengan cara mengganti cara pembiayaan bisa dilakukan semisal penggantian jangka waktu pembayaran dan meminta tempo semua dilakukan demi melancarkan pembayara $n$ yang sebelumnya tertunggak agar sesuai dengan keinginan kedua belah pihak yang melakukan perjanjian dan lancarnya kegiatan di finance.

2. Persyaratan kembali (reconditioning), yaitu proses pengkajian ulang pembayaran yang sudah dilakukan mencari letak kejanggalan yang menyebabkan penunggakan pembayaran ditambah mengetahui kemampuan peminjam dana dalam membayar angsuran guna memungkinkan dilanjutkannya pembayaran sampai lunasnya angsuran sesuai dengan perjanjian yang dilakukan kedua belah pihak.

3. Penataan kembali (restructuring), yaitu proses memulai lagi dari awal seperti saat melakukan pinjaman yang ada dikurangi dengan pembayaran yang telah dilakukan sebelumnya biasanya penataan kembali dilakukan oleh pihak finance dengan perusahaan bukan perorangan jadi jelas dana yang didapat sehingga memungkinkan dibuatnya perjanjian ulang dengan kesepakatan yang berbeda.

Pemerintah sebagai pengamat keuangan negara memberitahukan kepada pihak koperasi secara berulang-ulang agar teliti dalam melakukan transaksi teruta ma dalam bidang keuangan karena sedikit melakukan kesalahan akan berpengaruh besar kepada perusahaan begitu sebaliknya semakin efisien dalam melakukan suatu pekerjaan hasil yang diperoleh akan dinikmati seluruh penghuni perusahaan tanpa kecuali. Koperasi Sumber Kasih Tangeb menjadi contoh kesalahan kecil yang dibuat tanpa disadari secara terus menerus melakukan pemberian pinjaman tanpa memikirkan nilai dari suatu jaminan yang digunakan debitur membuat kewalahan pihak koperasi dalam upaya mengembalikan dana yang dipinjam debitur tanpa terjadi kerugian dari pihak bank sendiri.

Setiap permasalah pasti ada jalan tengah demi kebaikan kedua pihak, kebanyakan pihak yang mengambil jalur non litigasi permasalahannya selesai dengan waktu singkat namun tidak semua penyelesaian secara non litigasi menemukan titik tengah. Perselisihan anta ra pihak yang bersitegang bahwasanya pihaknya benar membuat non litigasi tidak dapat dilakukan maka beralih ke jalur litigasi (Fuady, 2002). Persetujuan hakim diperlukan sebelum memulai sidang perkara wanprestasi, menunggu selama seminggu minimal dilanjutkan pemanggilan pihak-pihak terkait dalam perjanjian seperti para pihak, saksi, pegawai koperasi yang menyaksikan perjanjian dibuat. Akhir sidang memutus salah satu pihak keluar sebagai pemenang, jika pihak nasabah menang akan mendapatkan ganti rugi dari pihak koperasi, jika pihak koperasi menang dalam persidangan maka berhak melelang jaminan milik nasabah sesuai isi perjanjian serta berhak meminta ganti rugi apabila hasil jual barang jaminan nasabah tidak mencukupi hutang nasabah.

\section{Penyelesaian Terhadap Kredit Macet di KSU Sumber Kasih Desa Tangeb}

Terjadinya kesalahan dalam memberikan pinjaman namun tidak memperhitungkan nilai tukar suatu jaminan membuat koperasi menjadi rugi dan susah menuntut pihak debitur karena kesalahan fatal ada pada koperasi bukan berarti pihak debitur bisa lepas begitu saja sebagai masyarakat yang taat aturan pihak debitur juga wajib melunasi sisa pembayaran atau wanprestasi dari perjanjian yang disepakati antara pihak bank dan pihak debitur yang bersifat mengikat bagi kedua pihak yang bersangkutan. Tidak terjalin komunikasi yang baik antar pihak koperasi baik antara atasan dengan staf atau sebaliknya terkait jaminan pinjaman yang diajukan masyarakat terjadinya penurunan nilai saham yang dimiliki bank, bagaimana tidak seseorang dapat dengan gampang meminjam modal untuk urusan 
tertentu dengan jumlah berapapun namun jaminan yang digunakan tidak memiliki nilai sama dengan dana yang dipinjam.

Pemerintah sebagai pengamat keuangan negara memberitahukan kepada pihak bank secara berulangulang agar teliti dalam melakukan transaksi terutama dalam bidang keuangan karena sedikit melakukan kesalahan akan berpengaruh besar kepada perusahaan begitu sebaliknya semakin efisien dalam melakukan suatu pekerjaan hasil yang diperoleh akan dinikmati seluruh penghuni perusahaan tanpa kecuali.

Koperasi Sumber Kasih Tangeb menjadi contoh kesalah kecil yang dibuat tanpa disadari secara terus menerus melakukan pemberian pinjaman tanpa memikirkan nilai dari suatu jaminan yang digunakan debitur membuat kewalahan pihak buana finance dalam upaya mengembalik an dana yang dipinjam debitur tanpa terjadi kerugian. Setelah dilakukannya prosedur penanganan pembiayaan bermasalah oleh pihak Sumber Kasih. Pembiayaan bermasalah/kredit macet tersebut dapat diselesaikan. Dari hasil wawancara yang dilakukan peneliti, dapat diketahui bahwa dalam mencegah dan mengatasi pembiayaan bermasalah pada Koperasi Sumber Kasih telah dilakukan dengan baik. Yaitu melakukan identifikasi masalah yang dihadapi oleh nasabah dengan melakukan tindakan Rescheduling, Reconditioning, Restructuring dan melakukan menyita barang jaminan.

\section{SIMPULAN DAN SARAN}

\section{Simpulan}

Kredit macet pada Koperasi Sumber Kasih Tangeb disebabkan karena musibah yang menimpa peminjam semisal terkena bencana alam dan meninggal dunia, pinjaman tanpa sepengetahuan orang tua, keadaan ekonomi yang tidak stabil, dan pemutusan hubungan kerja kreditur di perusahaan tempat kerjanya. Dalam penerapan perlindungan dana Koperasi Sumber Kasih Tangeb menerapkan prinsip dalam pembiayaan namun proses penerapan yang dilakukan belum cukup baik, pihak Sumber Kasih memberikan pembiayaan dengan menekankan prinsip 5C yang meliputi Character, Capacity, Capital, Condition dan Collateral. Namun lebih mengutamakan pada aspek analisis Character (karakter), Capacity (kemampuan), dan Collateral (jaminan). Hal yang paling penting dalam pemberian pembiayaan kepada nasabah atau calon nasabah adalah collateral (jaminan). prinsip 5C belum sepenuhnya dapat mencegah pembiayaan bermasalah karena kurang berhati -hatinya Account officer (AO) dalam menganalisis pembiayaan. Koperasi Sumber Kasih Tangeb dalam mencegah dan mengatasi kredit macet dilakukan dengan dua tahap tindakan lanjutan yakni tahap pertama dengan menerapkan Preventive Control Of Financing yaitu dengan cara melakukan analis pembiayaan, menetapkan batas maksimum pemberian pembiayaan dan melakukan pemantauan. Yang kedua dengan Repressive Control Of Financing, yakni dengan melihat penyebab pembiayaan bermasalah/kredit macet baik dari intern PT. Buana Finance cabang Denpasar. Biasanya menerapkan perpanjangan kredit melalui kesepakatan kedua belah pihak melalui jalur negosiasi agar tidak sampai ke proses persidangan.

\section{Saran}

Semua perangkat Koperasi Sumber Kasih Tangeb lebih teliti saat melakukan serangkaian prosedur terhadap nasabah terkait prinsip kehati-hatian untuk mengatasi kredit macet. Account Officer (AO) lebih memperhatikan perkembangan kondisi nasabah pembiayaan, baik dari lingkungan pribadi maupun lingkungan usahanya dengan memonitoring atau melakukan pembinaan Koperasi Sumber Kasih Tangeb agar bisa lebih tegas terhadap nasabah -nasabah yang bermasalah. Koperasi Sumber Kasih Tangeb perlu menyediakan SDM yang memadai untuk menunjang kegiatan operasionalnya agar dapat melakukan program pendampingan insentif terhadap calon nasabah yang memperoleh pembiayaan sehingga dapat memperkecil risiko yang tim bul dari pembiayaan kredit macet tersebut. Sebagai debitur yang memiliki perjanjian dengan pihak koperasi agar senantiasa mentaati peraturan yang telah disepakati bersama.

\section{DAFTAR PUSTAKA}

Ahmad, B. (2008). Metode Penelitian Hukum. Pustaka Setia, Bandung.

Atmadja, I Dewa Gede Budiartha, I. N. P. (2018). Teori-Teori Hukum. Setara Press, Malang.

Fuady, M. (2002). Pengantar Hukum Bisnis, Menata Bisnis Modern di Era Global. PT. Citra Aditya 
Bakti, Bandung.

Hermansyah. (2003). Hukum Perbankan Indonesia. PT. Raja Grafindo Persada, Jakarta.

Sari, N. L. A. S. H., Indrawati, A. A. S., \& Putrawan, S. (2019). Penyelesaian Kredit Macet Pada Koperasi Simpan Pinjam Karya Artha Sedana dan KSP. Wirartha Utama dikota Denpasar Selatan. Kertha Semaya, 7(8), 1-17.

Suarjaya, I. N. (2015). Analisis Penyelesaian Kredit Macet Pada Koperasi Pasar Srinadi Klungkung. Jurnal Pendidikan Ekonomi Undiksha, 5(1), 1-11.

Surya, I. P., Sukandia, I. N., \& Styawati, N. K. A. (2021). Penyelesaian Kredit Macet Melalui Upaya Litigasi di Koperasi Simpan Pinjam Surya Mandiri di Kabupaten Gianyar. Jurnal Interpretasi Hukum, 2(2), 440-446.

Uchsan, A. (2001). Hukum Perdata. Pembimbing Masa, Jakarta.

Waluyo, B. (2002). Penelitian Hukum Praktek. Sinar Grafika, Jakarta. 